MINERALOGIA, 50, No 1-4: 13-33 (2019)

DOI: 10.2478/mipo-2019-0002

www.Mineralogia.pl

Mineralogical SOCIETY of Poland

PolskiE TOWARZYSTWO MINERALOGICZNE

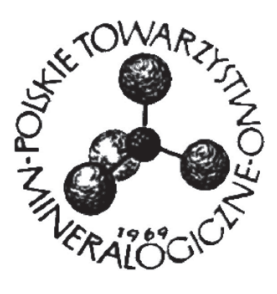

Original paper

\title{
Lamprophyric rock locations in Greece
}

\author{
loannis-Nektarios G. Kamvisis ${ }^{1 "}$ \\ ${ }^{1}$ Consultant Geologist's office, Greek Ministry of Defence, 227 Mesogion av., Athens, Greece \\ * Correspondence: \\ e-mail: alexanderellas@yahoo.com
}

Received: June 6, 2019

Received in revised form: September 10, 2019

Accepted: September 11, 2019

Available online: November 1, 2019

Abstract. Twenty-four areas with lamprophyric formations have been located through a bibliographic search in Macedonia, Thrace, the islands and Attica. Most lamprophyre types have been identified including rare "alkali minette". In most localities the dikes/sills appear to be late mantle products associated with deep faulting following extensional activity in granitoids.

Key-words: lamprophyric rocks, distribution, Greece, bibliography

\section{Introduction}

According to the Glossary of Geology (Neuendorf et al. 2005) the term lamprophyric describes rocks with holocrystalline-porphyritic texture exhibited by lamprophyres in which mafic phenocrysts occur in a fine-grained crystalline groundmass. Picritic rocks are excluded (Woolley et al. 1996).

The word "lamprophyre", first used by von Gumbel in 1874 for certain micaceous porphyritic dikes from the Bohemian massif, comes from the Greek word "lampros" which means bright. The ending - "phyre"-, which comes from "porphyry"-, describes the rock's porphyritic nature. Lamprophyres are defined as mesocratic to melanocratic porphyritic hypabyssal rocks, containing mafic phenocrysts such as micas, amphiboles and to some extent clinopyroxene. Feldspars or foids are confined to the groundmass which may also contain any of the above mafic minerals. Geochemically, lamprophyres tend to have a higher $\mathrm{K}_{2} \mathrm{O}, \mathrm{Na}_{2} \mathrm{O}$, volatiles $\left(\mathrm{H}_{2} \mathrm{O}, \mathrm{CO}_{2}\right), \mathrm{S}, \mathrm{P}_{2} \mathrm{O}_{5}$ and $\mathrm{Ba}$ content than mineralogically similar rocks (Le Maitre 2002). 
According to the I.U.G.S. the lamprophyre nomenclature includes the calc-alkaline minette, kersantite, spessartite, vogesite and the alkaline sannaite, camptonite, monchiquite (for detailed mineralogy see Streckeisen 1978 and Le Maitre 2002).

There are also ultramafic lamprophyres such as aillikite, damtjernite, ouachitite and turjite. All four types contain primary carbonate in their matrix. As the carbonate content increases they grade into carbonatites.

Alnöites, bergaliths, farrisites, luhites, modlibovites, polzenites and vesecites, on the other hand, have been classified together with melilitic rocks because they contain $>10 \%$ vol. melilite (Woolley et al. 1996; Le Maitre 2002). Recently however, they were reintroduced as melilite-bearing ultramafic lamprophyres (Tappe et al. 2005; Ulrych et al. 2014). There is also a long list of local and lesser known or obscure lamprophyre types.

Despite their uniqueness and puzzling character, compared to most igneous rocks (Prelević 2010), lamprophyres hold an important role in understanding mantle processes since they are considered windows into the deep mantle. Minettes, for example, are formed at a depth of 60-190 km (O'Neill, Wyman 2006). Lamprophyres generally show high concentrations of incompatible elements (Table1), which appears to exclude any origin by partial melting of typical spinel and pyrope lherzolite mantle, as very low degrees of partial melting $(<1 \%)$ would be required. They have to be derived from enriched or metasomatized mantle sources. This could take place with the transportation of small volume partial meltsfluids over time or with the input of $\mathrm{H}_{2} \mathrm{O}$ rich fluids from subduction zones (Wilson 1989). However, many lamprophyre mineral assemblages appear to be hybrid and from diverse sources. This includes autometasomatism and "frozen" or arrested products of various complex resorption reactions. Therefore, few inferences from natural bulk rocks (experiments or analyses) will have any relevance to those source magmas. The "liquid lamprophyre magma question" is still unresolved (Rock 1991).

The scope of this paper is to locate lamprophyric rocks in Greece, aiming to help future geologists in their studies of Greek lamprophyres. Similar surveys have taken place for example in Greece (Kamvisis 2010), in the Bohemian massif (Krmíček 2010) and Slovakia (Spišiak 2010).

\section{Method and results}

Lamprophyres were first discovered in Greece by the French geologist F.A.Fouque in 1879 during his geological expedition in Santorini (Thera) island. His work is still considered a valid tool for field geologists who study the caldera of Santorini. Through the years, more areas have been discovered in mainland northern and southern Greece and the Greek islands of the Aegean Sea.

After an extensive bibliographic search twenty-four areas have been identified. In relation to the main isopic zones, six areas were found in the Circum-Rhodope belt $(9,10$, $11,12,15,22)$, six within the Attic-Cycladic complex $(3,6,16,18,19,20)$, four within the Pelagonian zone $(2,8,14,24)$, four in the Serbo-Macedonian massif $(1,4,13,17)$, three in the Rhodope massif $(7,21,23)$, and one in the Gavrovo-Tripolitza zone(5). The twentyfour areas of Greece (with indicative coordinates) are the following (Fig. 1): 


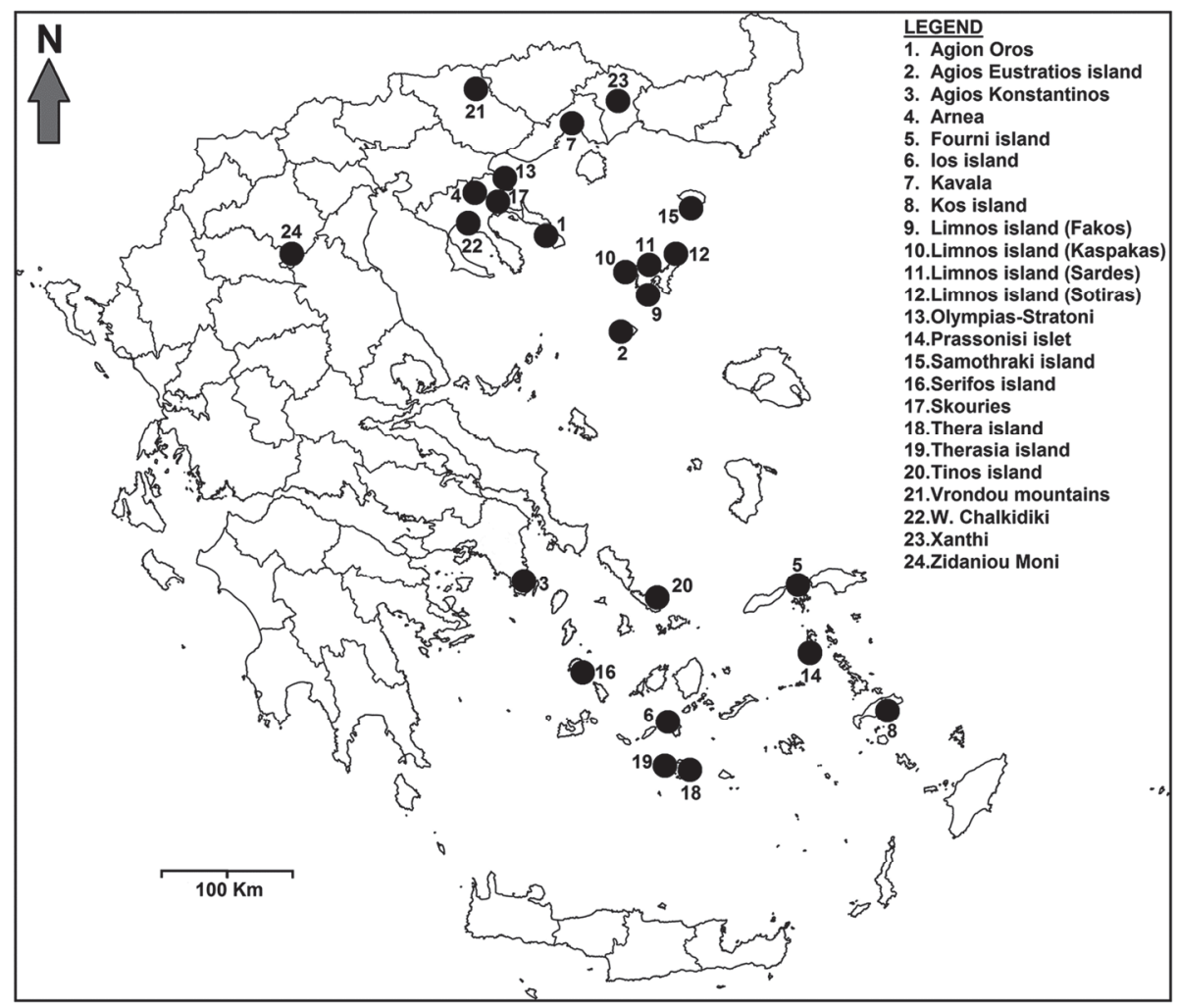

Fig. 1. Prefectural map of Greece showing the distribution of lamprophyric rocks (dots).

\subsection{Agion Oros Peninsula Autonomous Region, Macedonia, northern Greece}

(Georgiades 1938; Rock 1991)

N 40.186096, E 24.252068

A single kersantite dike intrudes the Osiou Gregoriou granitoid pluton in the area between Moni Osiou Gregoriou and Moni Simonos Petras (for whole-rock analysis see Table 1).

\subsection{Agios Eustratios island, Prefecture of Lesvos, Aegean Sea}

(Ktenas 1928; Johannsen 1938; Tröger 1969; Tomkeieff et al. 1983; Rock 1991; Le Maitre 2002; Neuendorf et al. 2005)

N 39.513865, E 24.975069

Several camptonite dikes, 4 to $5 \mathrm{~m}$ wide, cut the volcanic formations in Lidario in the western part of the island. This melanocratic rock has rare phenocrysts of olivine, corroded hornblende and augite in a groundmass composed of idiomorphic augite, titanomagnetite $\left[\mathrm{Fe}^{2+}\left(\mathrm{Fe}^{3+}, \mathrm{Ti}\right)_{2} \mathrm{O}_{4}\right]$, interstitial feldspar, mica and glass (Table1). 


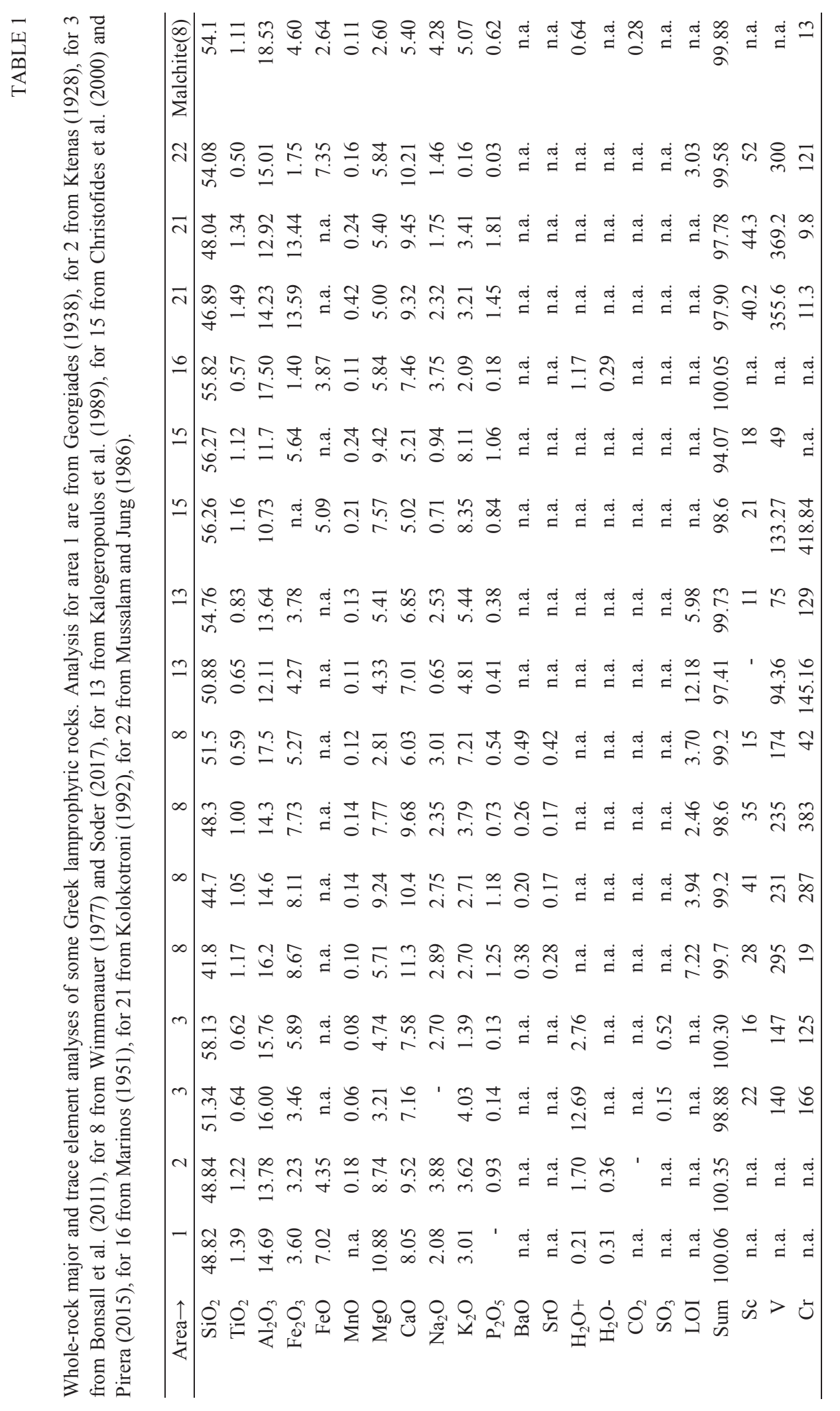




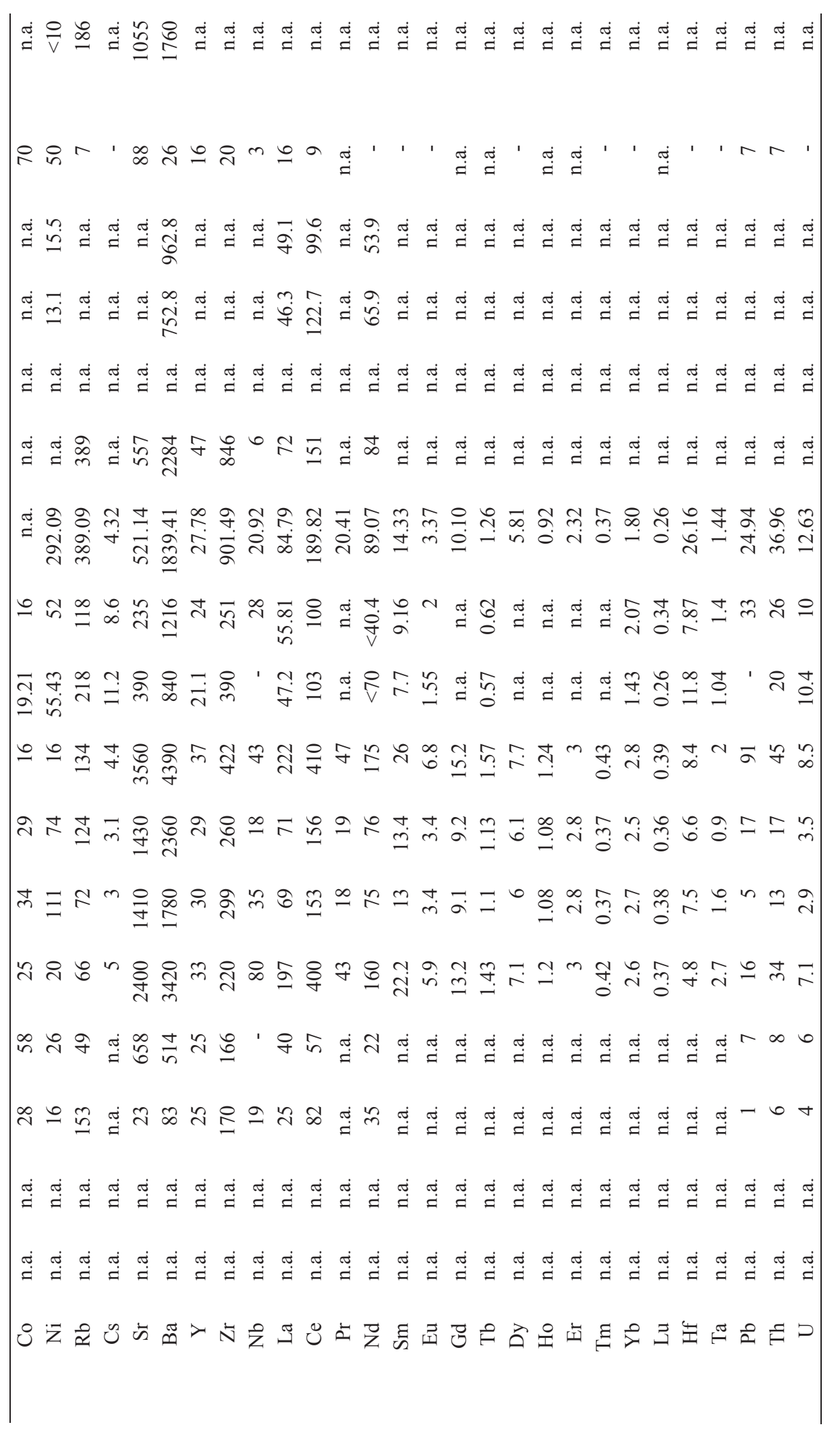




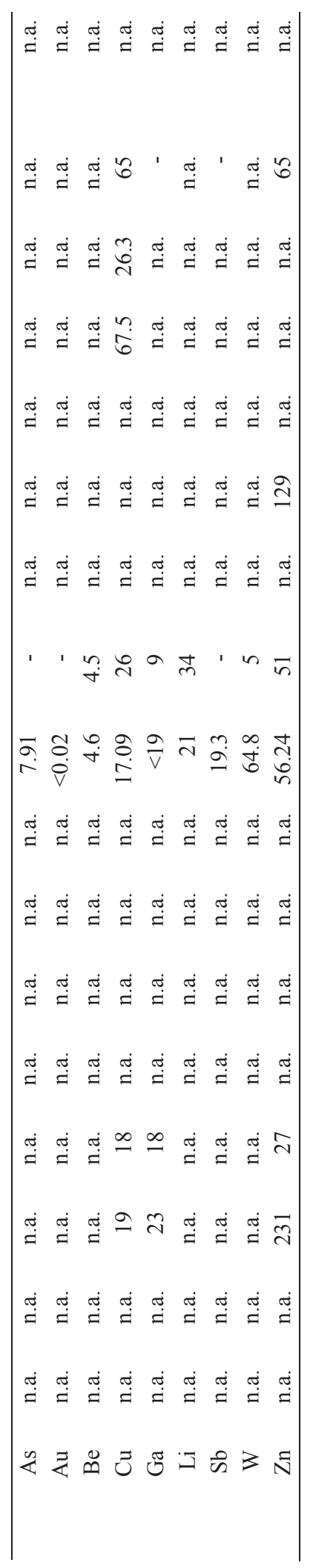




\subsection{Agios Konstantinos area, Prefecture of Attica, southern Greece}

(Bonsall 2008; Bonsall et al. 2011)

N 37.724634, E 24.026928

Three lamprophyric dikes have been found in the North Serpieri deposit near the Agios Konstantinos settlement in the vicinity of Lavrion. Two show propylitic alteration and the other sericitic alteration (Table 1).

\subsection{Arnea area, Prefecture of Chalkidiki, Macedonia, northern Greece}

(Oladeji 1997; Perugini et al. 2004; Christofides et al. 2007)

N 40.546429, E 23.584956

Numerous mesocratic-melanocratic minette and vogesite dikes and sills (color index up to 75) intrude the Arnea A-type granitoid. The dikes are from a few $\mathrm{cm}$ to $3 \mathrm{~m}$ wide and 10 to $15 \mathrm{~m}$ long. They are found along the Arnea-Palaeochora national road, near the village of Stanos, Paliokastro and around the hills of Giagova, Milopetra and Profitis Elias NNE of Arnea. Some of the dikes are weathered and show foliation.

\subsection{Fourni island, Prefecture of Samos, Aegean Sea}

(Georgalas 1924)

N 37.632252, E 26.505924

A $20 \mathrm{~cm}$ wide and $100 \mathrm{~m}$ long dark green vogesitic dike cuts the mica schists in the northern part of the island, NW of the Chryssomilia settlement and up to Phanos near the sea. It is possibly connected to an underwater pluton (Katsikatsos in press).

\subsection{Ios island, Prefecture of Cyclades, Aegean Sea}

(Maar 1980; 1981a; 1981b; Maar, Jansen 1983; Pe-Piper, Piper 2002)

N 36.734698, E 25.275187

A couple of weakly metamorphosed oblong mafic bodies intrude the garnet-mica schist zone near the augengneiss in the basement complex of Ios. The two exposures are north of Ios town. The rocks contain sericitized relicts of brown hornblende, allanite $\left[(\mathrm{Ce}, \mathrm{Ca}, \mathrm{Y}, \mathrm{La})_{2}\left(\mathrm{Al}, \mathrm{Fe}^{3+}\right)_{3}\left(\mathrm{SiO}_{4}\right)_{3}(\mathrm{OH})\right]$, biotite, albite and some quartz. They were identified as meta-lamprophyres.

\subsection{Kavala area, Prefecture of Kavala, Macedonia, northern Greece}

(Voudouris et al. 2016; Xydous 2018)

N 40.960313, E 24.438440 
Several lamprophyre dikes crosscut sheeted veins and the Kavala granodiorite pluton on the highway to Thessaloniki. They have a modal composition of biotite-hornblende quartz monzodiorite. The lamprophyres originated in metasomatized upper mantle and have been associated with an intrusion-related gold deposit.

\subsection{Kos island, Prefecture of Dodecanese, Aegean Sea}

(Altherr et al. 1976; 1988; Wimmenauer 1977; Rock 1991; Stouraiti 1995; Kalt et al. 1998; Altherr, Siebel 2002; Pe-Piper, Piper 2002; 2007a; 2007b; Pe- Piper et al. 2005; Pe-Piper, Moulton 2008; Tsoukalas 2008; Zouzias 2011; Soder 2015; Soder et al. 2016; Pandey et al. 2017; Soder 2017; Stouraiti et al. 2018)

N 36.817775, E 27.185507

Forty-four lamprophyre dikes cut the deformed Mount Dikeos monzonite massif, the older basement series and the faulted margin of the monzonite against the country rock. The massif is located at the eastern edge of the South Aegean volcanic arc in a retreating subduction zone where melting of the metasomatized mantle wedge is taking place. Crustal contamination of the dikes here may reach $50 \%$. The total area over which the rocks are exposed is $2.5 \mathrm{~km}^{2}$.

The majority of the dikes, especially those NE of Rachi ridge, have been classified as kersantites. There are also spessartites $1.1 \mathrm{~km}$ ENE of Eleona, minettes in a small valley $1 \mathrm{~km}$ SE of Eleona, biotite-fourchites between Eleona and Damia (containing picotite $\left.\left(\mathrm{Fe}^{2+}, \mathrm{Mg}\right)(\mathrm{Al}, \mathrm{Cr})_{2} \mathrm{O}_{4}\right)$ and finally vogesites. Biotite-malchite dikes were identified on the coast between Eleona and Damia (Table 1). The thickness of the dikes ranges from a few $\mathrm{cm}$ to $20 \mathrm{~m}$.

Lamprophyres are well known in collision zones but rarely along volcanic arcs, which is why Kos is an unusual example of lamprophyric magmatism.

\subsection{Limnos island (Fakos area), Prefecture of Lesvos, Aegean Sea}

(Voudouris 2006; Voudouris 2010; Djiba et al.2018; Sutphin et al. 2013)

N 39.816331, E 25.167514

In the southern part of the island of Limnos, in the Fakos peninsula, lamprophyre dikes intrude the Fakos quartz-monzonite porphyry subvolcanic body.

\subsection{Limnos island (Kaspakas area), Prefecture of Lesvos, Aegean Sea}

(Djiba et al. 2018)

N 39.913500, E 25.079716

At the coastal village of Kaspakas, in the western part of the island, lamprophyre dikes crosscut a sericitically altered trachydacite porphyry. 


\subsection{Limnos island (Sardes area), Prefecture of Lesvos, Aegean Sea}

(Djiba et al. 2018)

N 39.941606, E 25.141025

Lamprophyre dikes intrude the trachydacite porphyry near the mountain village of Sardes.

\subsection{Limnos island (Sotiras area), Prefecture of Lesvos, Aegean Sea}

(Roussos 1993)

N 40.007945, E 25.390676

In northeastern Limnos, in the Sotiras headland (Agios Charalambos Bay), a single $1 \mathrm{~m}$ wide dike cuts molasse sediments. The lamprophyre is melanocratic with biotite, clinopyroxene and serpentinized olivine phenocrysts in a feldspathic groundmass which also contains the previous mafic minerals.

\subsection{Olympias-Stratoni area, Prefecture of Chalkidiki, Macedonia, northern Greece}

(Nicolaou 1960; Papadakis 1971; Nicolaou, Kokonis 1980; Kalogeropoulos et al. 1989; 1991; Maltezou et al. 1989; Kilias et al. 1996; Haines 1998, Christofides et al. 2007; Modis, Komnitsas 2007; Michailidis, Sofianska 2010; European Goldfields 2011; Poli et al. 2012; Nestorov 2013; Vasilatos 2013; Arvanitidis 2018)

N 40.600754, E 23.748452

Numerous lamprophyre dikes $(>27)$ intrude the basement metamorphics of the Kerdylia Formation and the Stratoni granodiorite. The dikes are sometimes tens of meters wide and follow the direction of deep NE-SW faults. They have been characterized as highly contaminated mantle melts (containing fuchsite $\left.\mathrm{K}(\mathrm{Al}, \mathrm{Cr})_{2}\left(\mathrm{AlSi}_{3} \mathrm{O}_{10}\right)(\mathrm{OH})_{2}\right)$.

More specifically, lamprophyres have been found in the Olympias mines, the Vathilakkos gorge E of Madem Lakkos, in Vagionia, Stratoni, Mavres Petres W of Madem Lakkos and in some boreholes in the broader area. Seven borehole samples showed that the predominant lamprophyres in the Olympias mines are minettes (Kalogeropoulos et al. 1991). According to six whole-rock major and trace element geochemical analyses, four of the minettes are ultrapotassic (see Table 1).

In all the other localities, including gallery 173 of the Kassandra mines, the rocks were classified as spessartites.

\subsection{Prassonisi islet, Prefecture of Dodecanese, Aegean Sea}

(Galeos 1993)

N 37.267724, E 26.559506 
On the Prassonisi islet south of Patmos island, a dike cutting the islet's microsyenite carries lamprophyric xenoliths. These are composed exclusively of hornblende and biotite.

\subsection{Samothraki island, Prefecture of Evros, Thrace, Aegean Sea}

(Christofides et al. 2000; 2007; Perugini et al. 2004; Pipera 2015)

N 40.397975, E 25.570140

Several contaminated dark grey minettes intrude the southwestern Samothraki granitoid pluton. Two whole-rock geochemical analyses (see Table 1) showed that the rocks are ultrapotassic and peralkaline. Some other values are also typical of lamproitic rocks. Additionally, due to the high $\mathrm{Mg} / \mathrm{Fe}$ ratio, these rocks contain phlogopite laths instead of biotite (Woolley et al. 1996).

The rocks, on the other hand, contain plagioclase in their groundmass, a mineral commonly found in lamprophyres but not lamproites. In addition to plagioclase, lamproitic rocks totally lack all Na-leucophases (Mitchell, Bergman 1991; Le Maitre 2002).

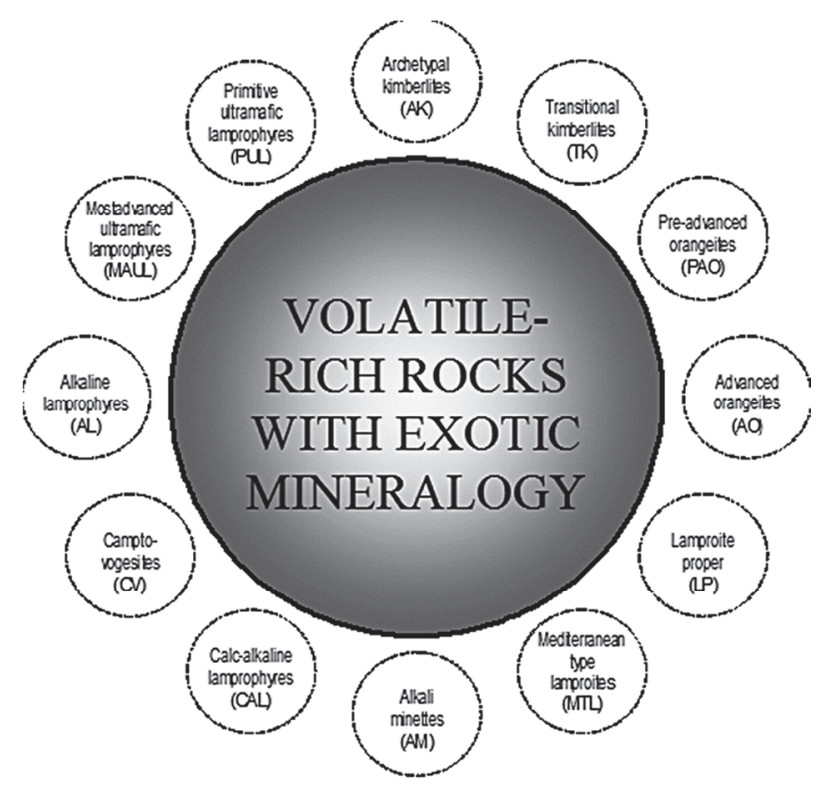

Fig. 2. Circular diagram (Kamvisis 2010) showing a possible continuum among some volatile-rich porphyritic rocks with exotic mineralogy and/or composition. Note that all groups lack plagioclase phenocrysts. $\mathrm{AK}=$ intracratonic basaltic kimberlites, $\mathrm{TK}=$ rocks petrographically and geochemically intermediate between kimberlites and orangeites, $\mathrm{PAO}=$ micaceous peri-cratonic kimberlites, $\mathrm{AO}=$ orangeites with $\mathrm{K}$-richterite, groundmass sanidine and $\mathrm{Zr}$-silicates like wadeite, $\mathrm{LP}=$ anorogenic olivine lamproites, $\mathrm{MTL}=$ orogenic phlogopite lamproites sometimes containing crustal plagioclase (Prelević et al. 2007), $\mathrm{AM}=$ ultrapotassic and peralkaline phlogopitic minettes with lamproitic characteristics, $\mathrm{CAL}=$ minettes, kersantites, spessartites and vogesites, $\mathrm{CV}=$ mafic vogesites bearing brown amphibole, $\mathrm{AL}=$ sannaites, camptonites and monchiquites, $\mathrm{MAUL}=$ melanocratic ultramafic lamprophyres having $>10 \%$ felsic minerals (e.g. ouachitites), $\mathrm{PUL}=$ holomelanocratic damtjernites to aillikites with $>15 \% \mathrm{MgO}$ (Francis, Patterson 2009). 
All these point to a rare kind of minette known as "alkali minette" (Woolley et al. 1996). "Alkali minettes" could be considered as transitional between minettes and Mediterranean-type lamproites (see Fig. 2). There are only a few examples of "alkali minettes" worldwide mainly associated, like Mediterranean-type lamproites, with major late to post-collisional igneous activity.

Three separate magmatic processes may contribute towards the formation of "alkali minettes" (Peterson et al. 1994; Prelević 2010). The first is mixing lamproitic and minette magmas. The second involves source regions that have a transitional character while in the third the composition of lamproite magma changes to minette magma when passing through the Earth's crust. These dikes have high $\mathrm{MgO}, \mathrm{Cr}$ and $\mathrm{Ni}$ contents together with high contents of incompatible elements which could not have originated from granitic contamination. The rock's source is highly metasomatized lithospheric mantle.

\subsection{Serifos island, Prefecture of Cyclades, southern Aegean Sea}

(Marinos 1951; Petrakakis et al. in press)

N 37.127544, E 24.457196

Late lamprophyre sills and dikes intrude the Serifos granodioritic pluton in the southeastern part of the island, along with more felsic lavas such as rhyolites, dacites, porphyries and aplites. In the Halara headland camptonite veins crosscut local marbles and gneiss (see Table 1). One of them is $>25 \mathrm{~m}$ long and $30 \mathrm{~cm}$ thick and has a distinct $5-10 \mathrm{~cm}$ thick skarn zone in contact with country rock (Ktenas 1917).

\subsection{Skouries area, Prefecture of Chalkidiki, Macedonia, northern Greece}

(Voudouris et al. 2016)

N 40.469631, E 23.703588

Near Neochori settlement, in eastern Chalkidiki, several lamprophyric dikes cut the Skouries porphyry. Small mela-syenite (durbachite) dikes also occur in the area (McFall et al. 2018). Durbachites are considered as the plutonic equivalents of calc-alkaline lamprophyres (Rock 1991).

\subsection{Thera/Santorini island, Prefecture of Cyclades, Aegean Sea}

(Fouque 1879)

N 36.406227, E 25.428519

During his journey in 1879, F.A.Fouque discovered numerous kersantitic blocks in the lowermost ash layer of the cliffs of Thera (the Caldera cliffs). Fouque concluded that the blocks must have been brought up from a granitoid (from the Basement Series). This statement proves to have been very reasonable since, nearly a century later, Puchelt (Puchelt et al. 1977) identified a granitic xenolith in the pumice of the Christiana islands, a few miles SW of Thera. Later, Skarpelis (Skarpelis et al.1992) found, through a $250 \mathrm{~m}$ 
deep borehole, that a granitoid body had indeed intruded the metamorphic basement of Santorini.

\subsection{Therasia island, Prefecture of Cyclades, Aegean Sea}

(Fouque 1879)

N 36.437786, E 25.349062

A very similar occurrence to that of Thera. In 1879 F.A.Fouque discovered a great number of kersantitic blocks in the volcanic ash at the bottom of the island's cliffs. The cliffs are probably those of the Therasia Shield Formation.

\subsection{Tinos island, Prefecture of Cyclades, Aegean Sea}

(Melidonis 1980; Pantziris 2000)

N 37.628971, E 25.194155

A few lamprophyre dikes and sills intrude the periphery of the N-NW Tinos granitoid.

\subsection{Vrondou mts, Prefecture of Serres, Macedonia, northern Greece}

(Kolokotroni 1992; Christofides et al. 1998; 2007; Soldatos et al.1998;

Perugini et al. 2004; Zananiri 2004; Pipera 2015)

N 41.200331, E 23.566788

In the area of the Vameno stream, between the villages of Orini and Xerotopos, three lamprophyre dikes cut the southern margins of the deformed Vrondou granitoid. They run sub-parallel to the margin. The lamprophyres are calc-alkaline (Table 1) and contain abundant coarse (up to $4 \mathrm{~mm}$ ) green to green-brown euhedral amphibole crystals, interstitial K-feldspar, subordinate plagioclase, minor quartz and accessory titanite, apatite and opaques.

According to Kolokotroni (1992) and Soldatos (1998) these lamprophyres formed during subduction. They are the precursors of High-K MME which formed through crystal fractionation of melts from an enriched lithospheric mantle source.

\subsection{W. Chalkidiki peninsula, Prefecture of Chalkidiki, Macedonia, northern Greece}

(Jung et al. 1981)

N 40.283411, E 23.444179

There are two lamprophyric dike swarms. One crosscuts the diorites of the Chortiatis suite and the other the Thessaloniki ophiolites. The dikes are centimeters to meters thick. They are dark, weakly porphyritic, have chilled margins and often a fluidal texture. They have a dioritic mineralogy with light green hornblende, intermediate plagioclase, and some 
epidote and opaques. Their composition, especially the trace elements, is also dioritic. It should be noted that Pe-Piper and Piper(2002) mention hornblende microdiorite dikes (Table 1) occurring along the SW margin of the Gerakini and Metamorphosis maficultramafic rocks. These have been related to extensional faulting (Mussallam, Jung 1986). Additionally, in the same area, there are some late porphyritic to microporphyritic sills of intermediate composition. They contain clinopyroxene and hornblende phenocrysts (40\%), plagioclase, quartz, accessory biotite (2-3\%) and pyrite (Mussallam, Jung 1986). These sills could be characterized as lamprophyric.

\section{Xanthi area, Prefecture of Xanthi, Thrace, northern Greece}

(Christofides 1977; Eleutheriadis 1986; Koukouvelas, Pe-Piper 1991; Sergi 1997; Pe-Piper, Piper 2002; Eleutheriadis, Koroneos 2004; Kokkinakis 2007; Papadopoulos 2011; Scarrow et al.. 2011; Pirera 2015)

N 41.148860, E 24.946263

Twenty-three dark green lamprophyre dikes and sills have been mapped by Koukouvelas and Pe-Piper between the city of Xanthi and the village of Filia. They follow early joints radially cutting the margin of the Xanthi pluton and earlier aplite veins. This particular subduction-related pluton is located on the Kavala-Komotini dextral strike-slip fault zone. The lamprophyres have been associated with continued regional NE-SW directed pull-apart extension at a classic locality for transtensional stress (a bend in the fault). The dikes are 0.5 to $1 \mathrm{~m}$ wide and can be traced up to $30 \mathrm{~m}$ along strike. There are also some small intrusions measuring $10 \times 10$ to $20 \times 100 \mathrm{~m}^{2}$. The rocks are calc-alkaline, composed of olive green amphibole phenocrysts (altered to epidote and chlorite) and a little pyroxene. Plagioclase is confined to the groundmass which also contains amphibole and sometimes K-feldspar and quartz. Occasionally they contain granodioritic inclusions.

\subsection{Zidaniou Moni area, Prefecture of Kozani, Macedonia, northern Greece}

(Netelbeek 1959; Anonymous 1978; Orris 1993)

N 40.084048, E 21.850717

Several lamprophyric sills and dikes intrude the southern part of the Vourinos ophiolitic complex $25 \mathrm{~km}$ SSE of the city of Kozani, between the villages of Mikrovalton, Tranovalton and Moni Zidaniou. This part of the complex is composed mainly of dunites and some more serpentinized rock types. The dunite is cut by a few dark lamprophyric dikes measuring up to $60 \mathrm{~cm}$ in width. In the more serpentinized ophiolites most lamprophyric rocks occur as brownish grey sills up to $15 \mathrm{~m}$ in length and sometimes as 'sliced dikes'. Most of the rocks are altered, deformed and have a rather schistose appearance due to shearing. The area also includes the Zidani asbestos mine where small lamprophyre dikes irregularly intersect the serpentinite. Additionally, lamprophyric dikes have been found in several deep boreholes (up to $150 \mathrm{~m}$ in depth).

The dominant minerals are brown biotite, actinolite and albite forming a fine-grained groundmass. Accessory minerals include apatite, rutile, magnetite and ilmenite. In one 
locality the rocks contain globular structures filled with albite and biotite. These structures are characteristic of lamprophyres and very common among them. The petrographic type here is a kind of lamproschist (for definition see Neuendorf et al. 2005).

Although it is uncommon for lamprophyres to occur in ophiolitic complexes, there have been a few confirmed examples from well-known ophiolites such as the Bayazeh ophiolite in central Iran (Bayat, Torabi 2011), the Haybi in the Semail ophiolitic complex of Oman (Searle 1984), the north Anatolian ophiolitic mélange (Gülmez et al. 2014), Unst in Scotland (Taylor 1988; Flinn, Oglethorpe 2005), and the Vedi ophiolite in Armenia (Satian et al. 2009).

\section{Discussion}

It is almost certain that more calc-alkaline lamprophyres will be discovered in the granodioritic and monzonitic massifs of Greece. On the other hand, alkaline lamprophyres have been connected around the world primarily with basanites and alkali basalts. The small $(75 \times 150 \mathrm{~m})$ intrusion $2 \mathrm{~km}$ E of Metamorphosis (Kilkis Prefecture, Macedonia) is one example. The intrusion (Melidonis 1972) contains kaersutite $\mathrm{NaCa}_{2}\left(\mathrm{Mg}_{3} \mathrm{Ti}^{4+} \mathrm{Al}\right)\left(\mathrm{Si}_{6} \mathrm{Al}_{2}\right) \mathrm{O}_{22}(\mathrm{OH})_{2}, \quad$ oxyhornblende $\quad \mathrm{NaCa}_{2}\left(\mathrm{Mg}, \mathrm{Fe}^{2+}, \mathrm{Fe}^{3+}, \mathrm{Al}, \mathrm{Ti}\right)_{5}$ $\left(\mathrm{Si}_{6} \mathrm{Al}_{2}\right) \mathrm{O}_{22}(\mathrm{O}, \mathrm{OH})_{2}$ and Ti-biotite $\mathrm{K}\left(\mathrm{Mg}_{2} \mathrm{Ti}\right)\left(\mathrm{Si}_{3} \mathrm{AlO}_{10}\right) \mathrm{O}_{2}$ phenocrysts (Fig.3). The rock has close affinities with camptonites (Le Maitre 2002). It appears to be related to the basanites found in the northern part of the Sava-Vardar-Axios suture zone. Another interesting formation, that could potentially be classified as lamprophyric, is the Achillion volcanics in central Greece (Innocenti et al. 2010).

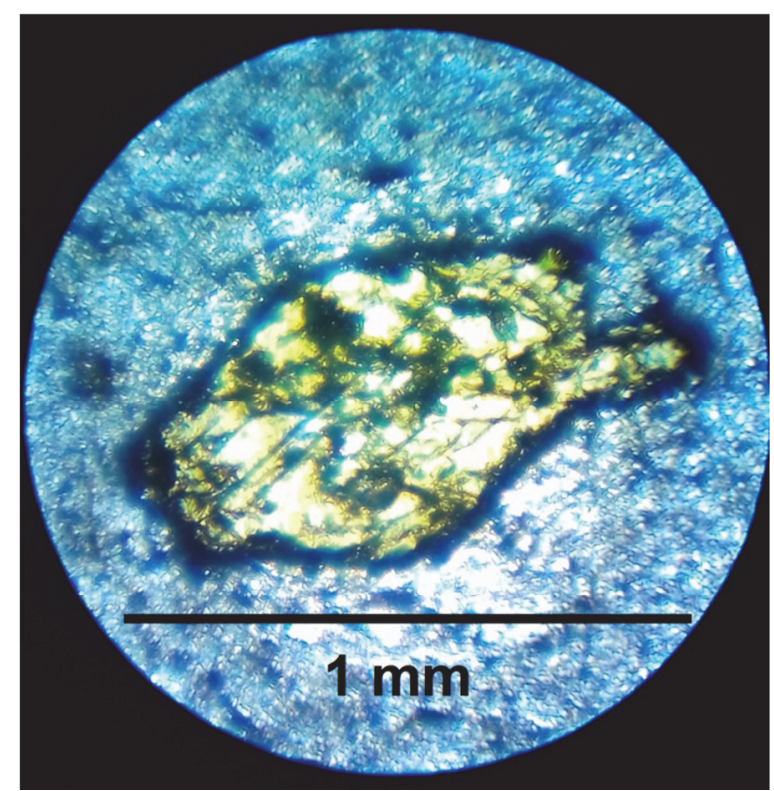

Fig. 3. Photomicrograph of a light brown amphibole phenocryst from the Kilkis intrusion. Groundmass is mainly oligoclase. 
The most prominent area however, for lamprophyric rocks to occur is in Thrace, close to the Greek-Bulgarian border. This area lies to the south and at a very small distance from the Krumovgrad intraplate camptonite dikes (Marchev et al. 1998). The eastern dikes are camptonites (Marchev et al. 2006). In the Kotza Ele mountain area of Bulgaria, near the source of the Juruklerska river, a diatreme lies only $200 \mathrm{~m}$ from the borderline $\mathrm{N}$ of the Greek village of Chloi (Marchev et al. 1998). An interesting formation of the broader area, which has to be more thoroughly examined, is a subvolcanic body described as porphyritic gabbrosyenite (IGME unpublished data). It is located in Mavrohorara.

\section{Conclusions}

Despite the uncommon nature of lamprophyric rocks twenty-three areas have been identified through a bibliographic search. Most lamprophyre types have been identified including vogesite, the rarest of all calc-alkaline lamprophyres (see Rock 1991). Semilamprophyric malchite and alkali minette have also been located. Almost all the above lamprophyres occur as dikes and occasionally as sills cutting granitoid plutons. They are considered to be the latest and deepest (mantle generated) igneous products, associated with deep faulting following extension in granodiorite and monzonite massifs. Lastly, lamprophyric rocks have been recognized within ophiolite complexes in Kozani and W.Chalkidiki.

\section{Acknowledgements}

I thank God for enabling me complete this article. I also thank G. Georgopoulos, Chr. Gounaris, M. Imelos, G. Karaiskaki, A. Mazarakou, V. Melfos, Th. Mitsogiannis, K.Mouchtouri, P. Nikolaidou, Th. Papaspiropoulos, I.Papazoglou, A. Sbokou, A. Vazika and the two reviewers that reviewed the manuscript.

\section{References}

Altherr, R., Henjes-Kunst, F., Matthews, A., Friedrichsen, H., \& Hansen, B.T. (1988). O-Sr isotopic variations in Miocene granitoids from the Aegean. evidence for an origin by combined assimilation and fractional crystallization. Contributions to Mineralogy and Petrology 100, 528541. DOI: $10.1007 / \mathrm{BF} 00371381$

Altherr, R., Keller, J., \& Kott, K. (1976). Der jungtertiäre Monzonit von Kos und sein Kontakthof (Ägäis, Griechenland). Bulletin de la Societe géologique de France 18(2), 207-216. DOI: 10.2113/gssgfbull.S7-XVIII.2.403[in German].

Altherr, R., \& Siebel, W. (2002). I-type plutonism in a continental back-arc setting. Miocene granitoids and monzonites from the central Aegean Sea, Greece. Contributions to Mineralogy and Petrology 143, 397- 415. DOI: 10.1007/s00410-002-0352-y

Anonymous (1978). Greek asbestos breaks ground.-Industrial Minerals 129, 47-49

Arvanitidis N. (2018). Halkidiki, Forged from Land and Sea. Stamoulis Press, Athens, Greece, $176 \mathrm{p}$

Bayat, F., \& Torabi, G. (2011). Alkaline lamprophyric province of Central Iran. Island Arc 20,386400. DOI: $10.1111 / \mathrm{j} .1440-1738.2011 .00776 . x$

Bonsall, T. (2008). The geochemistry of carbonate-replacement $\mathrm{Pb}-\mathrm{Zn}-\mathrm{Ag}$ mineralization in the Lavrion District, Attica, Greece. fluid inclusion, stable isotope, and rare earth element studies. MSc Thesis. Iowa State University, Ames, U.S.A.,84 p 
Bonsall, T., Spry, P., Voudouris, P., Tombros, S., Seymour, K., \& Melfos, V. (2011). The Geochemistry of Carbonate-Replacement $\mathrm{Pb}-\mathrm{Zn}-\mathrm{Ag}$ Mineralization in the Lavrion District, Attica, Greece. Fluid Inclusion, Stable Isotope, and Rare Earth Element Studies. Economic Geology 106, 619-651. DOI: 10.2113/ecogeo.106.4.619

Christofides, G. (1977). Contribution to the study of the plutonic rocks of Xanthi area PhD Thesis, University of Thessaloniki, Thessaloniki, Greece, 249 p [in Greek]

Christofides, G., Eleftheriadis, G., Esson, J., Soldatos, T., Koroneos, A., \& Brocker, M. (2000). The evolution of the Samothraki granitic pluton (N. Aegean Sea, Greece). Geochronology, chemical and isotopic constraints for AFC modeling. In. Panayides, I., Xenofontos, C. \& Malpas, J. (eds). Proceedings of the Third International Conference on the Geology of the Eastern Mediterranean, Nicosia, Cyprus, pp. 193-209

Christofides, G., Perugini, D., Koroneos, A., Soldatos, T., Poli, G., Eleftheriadis, G., Del Moro, A., \& Neiva, A.M. (2007). Interplay between geochemistry and magma dynamics during magma interaction. An example from the Sithonia Plutonic Complex (NE Greece). Lithos 95, 243-266. DOI: 10.1016/j.lithos.2006.07.015

Christofides, G., Soldatos, T., Eleftheriadis, G., \& Koroneos, A. (1998). Chemical and isotopic evidence for source contamination and crustal assimilation in the Hellenic Rhodope plutonic rocks. Acta Vulcanologica 10(2), 305-318.

Djiba, A., Voudouris, P., Bismayer, U., Spry, P., \& Alfieris, D. (2018). Porphyry-Epithermal Deposits Related to Alkaline Magmatism on Limnos Island, Northern Aegean Sea, Greece. Mineralogical Constraints and Genetic Considerations.- In. $8^{\text {th }}$ Geochemistry Symposium Abstract Book, Antalya, Turkey, pp. 146

Eleutheriadis, G. (1986). Notes on the petrology of igneous rocks. University of Thessaloniki, Thessaloniki, Greece, $134 \mathrm{p}$ [in Greek]

Eleutheriadis, G., \&Koroneos, A. (2004). Notes on the petrology of igneous rocks [in Greek].University of Thessaloniki, Thessaloniki, Greece, $243 \mathrm{p}$

European Goldfields (2011). Technical Report on the Olympias Project $\mathrm{Au} \mathrm{Pb} \mathrm{Zn} \mathrm{Ag} \mathrm{Deposit,}$ Northern Greece. Whitehorse, Canada, 213 pp

Flinn, D. \& Oglethorpe, R.J.D. (2005). A history of the Shetland Ophiolite Complex. Scottish Journal of Geology 41(2) 141-148. DOI: 10.1144/sjg41020141

Fouque, F.A. (1879). Santorin et ses éruptions. Masson et Cie, Paris, France, 440 p [in French]

Francis, D., \& Patterson, M. (2009). Kimberlites and aillikites as probes of the continental lithospheric mantle. Lithos 109, 72-80. DOI: 10.1016/j.lithos.2008.05.007

Galeos, A. (1993). Geological map of Greece - Patmos island sheet 1.50.000. I.G.M.E., Athens, Greece

Georgalas, G.C. (1924). Sur la constitution géologique des îles Phourni (entre Nikaria et Samos). Compte Rendu Hebdomadaire des Séances de l'Académie des Siences, Paris 179(13), 601-604 [in French]

Georgiades, A.N. (1938). La Kersantite du Couvent de St. Gregoire, dans le Mont Athos. Praktika Akademias Athenon 13, 487-491 [in French]

Gülmez, F., Genc, Ç., \& Prelević, D. (2014). Petrology and geochemistry of late Cretaceous lamprophyric rocks from North Anatolian Ophiolitic Melange-Turkey.-EGU General Assembly Conference Geophysical Research Abstracts 16

Haines, S. H. (1998). A structural synthesis for sector Vh of the Mademi Lakkos polymetallic sulphide deposit-Northeast Greece. MSc Thesis. University of London, London, U.K., $134 \mathrm{p}$

Innocenti, F., Agostini, S., Doglioni, C., Manetti, P., \& Tonarini, S. (2010). Geodynamic evolution of the Aegean. constraints from the Plio-Pleistocene volcanism of the Volos-Evia area. Journal of the Geological Society of London 167, 1-15. DOI: 10.1144/0016-76492009-149

Johannsen, A. (1938). A Descriptive Petrography of Igneous Rocks. Chicago University Press, Chicago, U.S.A., $523 \mathrm{p}$ 
Jung, D., Mussallam, K., Burgath, K., Kockel, F., Mohr, G., \& Raschka, H. (1981). Ultramafic and related rocks of Chalkidiki. An International Symposium on Metallogeny of Mafic and Ultramafic complexes, Athens, Greece, pp. 24-42

Kalogeropoulos, S.I., Gerouki, F., \& Papadopoulos, C. (1991). Mineralogy-Geochemistry - Genesis and Metallogenetic Significance of Lamprophyres from the Stratoni. Olympias area, Kerdilia Formation, Eastern Chalkidiki. Bulletin of the Geological Society of Greece 25(2), 161-173

Kalogeropoulos, S.I., Kilias, S.P., \& Bitzios, D.C. (1989). Genesis of the Olympias CarbonateHosted $\mathrm{Pb}-\mathrm{Zn}(\mathrm{Au}, \mathrm{Ag})$ Sulfide Ore Deposit, Eastern Chalkidiki Peninsula, Northern Greece. Economic Geology 84, 1210-1234. DOI: 10.2113/gsecongeo.84.5.1210

Kalt, A., Altherr, R., \&Ludwig, T. (1998). Contact Metamorphism in Pelitic Rocks on the Island of Kos (Greece, Eastern Aegean Sea). A Test for the Na-in-Cordierite Thermometer. Journal of Petrology 39(4), 663-688. DOI: 10.1093/petroj/39.4.663

Kamvisis, I.-N. (2010). Occurrences of lamprophyric rocks in Greece. Neues Jahrbuch fur Mineralogie Abhandlungen 187(2), 225-234. DOI: 10.1127/0077-7757/2010/0173

Katsikatsos, G. (in press). Geological map of Greece- Fourni island sheet 1.50.000. I.G.M.E., Athens, Greece

Kilias, S.P., Kalogeropoulos, S.I. \& Konnerup-Madsen, J. (1996). Fluid inclusion evidence for the physicochemical conditions of sulfide deposition in the Olympias carbonate-hosted $\mathrm{Pb}-\mathrm{Zn}(\mathrm{Au}$, Ag) sulfide ore deposit, E. Chalkidiki peninsula, N. Greece. Mineralium Deposita 31, 394-406. DOI: $10.1007 / \mathrm{BF} 00189187$

Kokkinakis, A. (2007). Magmatic rocks - $3^{\text {rd }}$ Ed. [in Greek]

Kolokotroni, C. (1992). The emplacement and petrogenesis of the Vrondou granitoid pluton, Rhodope massif, NE Greece. PhD Thesis. University of Edinburgh, Edinburgh, U.K., 487 p

Koukouvelas, I., \& Pe-Piper, G. (1991). The Oligocene Xanthi pluton, northern Greece. a granodiorite emplaced during regional extension. ,Journal of the Geological Society of London 148, 749-758. DOI: 10.1144/gsjgs.148.4.0749

Krmíček, L. (2010). Pre-Mesozoic lamprophyres and lamproites of the Bohemian Massif (Czech Republic, Poland, Germany, Austria). Mineralogia Special Papers 37, 37-46

Ktenas, K. (1917). Research about the metallogenessis of the S.E. Aegiis region. Publication of the University of Athens 13, 1-44 [in Greek]

Ktenas, C. A. (1928). Sur la présence des laves alcalines dans la mer Égée septentrionale. Compte Rendu Hebdomadaire des Séances de l'Académie des Siences, Paris 186, 1631-1633 [in French]

Le Maitre, R.W. (2002). Igneous rocks. a Classification and Glossary of Terms. Recommendations of the International Union of Geological Sciences Subcommission on the Systematics of Igneous Rocks. $2^{\text {nd }}$ Ed., Cambridge University Press, Cambridge, U.K., 236 pp

Maar, P.A. van der (1980). The geology and petrology of Ios, Cyclades, Greece. Annales Geologiques des Pays Helleniques 30, 206-224

Maar, P.A. van der (1981a). Geological map of Greece. Ios island sheet 1.50.000. I.G.M.E., Athens, Greece

Maar, P.A. van der (1981b). Metamorphism on Ios and the geological history of southern Cyclades, Greece. Geologica Ultraiectina 28, 1-142

Maar, P.A. van der, \& Jansen, J.B.H. (1983). The geology of the polymetamorphic complex of Ios, Cyclades, Greece and its significance for the Cycladic Massif. Geologische Rundschau 72, 283299. DOI: $10.1007 / \mathrm{BF} 01765910$

Maltezou, F., Kalogeropoulos, S., \& Hamilton, N. (1989). A geophysical study in the eastern Chalkidiki peninsula, N. Greece. the Stratoni granodiorite and its significance to metallogeny. In Proceedings of the Panhellenic Conferences on Geophysics, pp. 336-353

Marchev, P., Arai, S., \& Vaselli, O. (2006). Cumulate xenoliths in Oligocene alkaline basaltic and lamprophyric dikes from the eastern Rhodopes, Bulgaria. Evidence for the existence of layered 
plutons under the metamorphic core complexes. Geological Society of America Special Papers 409, 237-258

Marchev, P., Vaselli, O., Downes, H., Pinarelli, L., Ingram, G., Rogers, G., \& Raicheva, R. (1998). Petrology and geochemistry of alkaline basalts and lamprophyres. implications for the chemical composition of the upper mantle beneath the Eastern Rhodopes (Bulgaria). Acta Vulcanologica 10(2), 233-242

Marinos, G. (1951). The Geology and metallogenessis of the Island of Seriphos. Geological and Geophysical Surveys 1(4), 95-127. [in Greek].

McFall, K., Naden, J., Roberts, S., Baker, T., Spratt, J., \& McDonald. I. (2018). Platinum-group minerals in the Skouries Cu-Au (Pd, Pt, Te) porphyry deposit. Ore Geology Reviews 99, 344-364. DOI: 10.1016/j.oregeorev.2018.06.014

Melidonis, N.G. (1972). Der Bogen junger vulkanischer Gesteine zwischen Strymonikon und Metamorphosis (Mazedonien). Mineral Exploration 5, I.G.S.R., Athens, 51 p [in Greek].

Melidonis, N.G. (1980). Geological structure and ore deposits of Tinos island (Cyclades) I.G.M.E., Athens, $80 \mathrm{p}$ [in Greek].-

Michailidis, K., \& Sofianska, E. (2010). Spheroidal and radiating aggregates of Mn- pyroxenoids in the Olympias carbonate-hosted polymetallic sulphide ore deposit, E. Chalkidiki peninsula, N. Greece. Review of the Bulgarian Geological Society 71 (1-3), 59-68

Mitchell, R.H., \& Bergman, S.C. (1991). Petrology of Lamproites. Plenum Press, New York, U.S.A., $447 \mathrm{p}$

Modis K. \& Komnitsas K. (2007). Optimum sampling density for the prediction of acid mine drainage in an underground sulphide mine. In. Cidu, R. \& Frau, F. (eds). IMWA Symposium 2007: Water in Mining Environments, Cagliari, Italy, pp. 99-103

Mussallam, K., \& Jung, D. (1986). Petrology and geotectonic significance of salic rocks preceding ophiolites in the eastern Vardar Zone, Greece. Tschermaks mineralogische und petrographische Mitteilungen 35, 217-242. DOI: 10.1007/BF01191987

Nestorov, N. (2013). Geological modelling and Geostatistics- Research on the sulphide deposit of Maddem Lakkos Chalkidiki. MSc Thesis, University of Thessaloniki, Thessaloniki, Greece, $126 \mathrm{p}$ [in Greek]

Netelbeek, T.A.F. (1959). Lamprophyres in the ultrabasics south of Kozani. - Bulletin of the Geological Society of Greece 4(1), 6-10

Neuendorf, K.K.E., Mehl, J.P., \& Jackson, J.A. (2005). Glossary of Geology. - $5^{\text {th }}$ Ed., Springer Science and Business, $779 \mathrm{p}$

Nicolaou, M.M. (1960). L' intrusion granitique dans le région de Stratoni - Olympiade et sa relation avec la métallogenèse. Annales Géologiques des Pays Helléniques 11, 214-265 [in Greek]

Nikolaou M.M. \& Kokonis I. (1980). Geology and development of the Olympias mine, eastern Chalkidiki, Macedonia, Greece. In. Jones M.J. (eds). Complex sulphides ores, Institute Mining Metallurgy, London, U.K. pp. 260-270

Oladeji, A. J. (1997). Geology and Petrography of the Arnea granite, Chalkidiki Province [in Greek]. $\mathrm{PhD}$ Thesis. Aristotle University of Thessaloniki, Thessaloniki, Greece, $181 \mathrm{p}$

O’Neill, C., \& Wyman, D.A (2006). Geodynamic modelling of Late Archean subduction. Pressuretemperature constraints from greenstone belt diamond deposits.- Washington DC American Geophysical Union Geophysical Monograph Series 164, 177-188

Orris, G. (1993). Zidani. U.S. Geological Survey, Mineral Resources Data System. Retrieved April 7, 2019 from U.S. Geological Survey database: https.//mrdata.usgs.gov/mrds/

Pandey, A., Rao, N.V.C., Chakrabarti, R., Pandit, D., Pankaj, P., Kumar, A., \& Sahoo, S. (2017). Petrogenesis of a Mesoproterozoic shoshonitic lamprophyre dike from the Wajrakarur kimberlite field, eastern Dharwar craton, southern India: Geochemical and $\mathrm{Sr}-\mathrm{Nd}$ isotopic evidence for a modified sub-continental lithospheric mantle source. Lithos 292-293, 218-233. DOI: 10.1016/j.lithos.2017.09.001 
Pantziris, I. (2000). Geochemical-Petrological study of the basic-ultrabasic rocks of the islands of the Aegean. PhD Thesis. University of Athens, Athens, Greece, $466 \mathrm{p}$ [in Greek]

Papadakis, A. (1971). On the age of the granitic intrusion near Stratonion, Chalkidiki (Greece). Annales Géologiques des Pays Helléniques 23(1), 297-300 [in Greek]

Papadopoulos, A. (2011). Natural radioactivity in relation to mineralogy, Uranium and Thorium geochemistry of magmatic rocks from the vicinity of Greece: Contribution to the use of natural construction materials. PhD Thesis. Aristotle University of Thessaloniki, Thessaloniki, Greece, $297 \mathrm{p}$ [in Greek]

Pe-Piper, G., \& Moulton, B. (2008). Magma evolution in the Pliocene-Pleistocene succession of Kos, South Aegean arc (Greece). Lithos 106, 110-124 DOI: 10.1016/j.lithos.2008.07.002

Pe-Piper, G., \& Piper, D.J.W. (2002). The igneous rocks of Greece. Gebrüder Borntraeger, Stuttgart, $645 \mathrm{p}$

Pe-Piper, G., \& Piper, D.J.W. (2007a). Late Miocene igneous rocks of Samos. the role of tectonism in petrogenesis in the southestern Aegean.- In. Taymaz T., Yilmaz Y. and Dilek Y. (eds.). The Geodynamics of the Aegean and Anatolia. Geological Society of London Special Publications 291. pp. 75-97 DOI: $10.1144 /$ SP291.4

Pe-Piper, G. \& Piper, D.J.W. (2007b). Neogene backarc volcanism of the Aegean. New insights into the relationship between magmatism and tectonics.- In. Beccaluva, L., Bianchini, G., \& Wilson, M. (eds). Cenozoic Volcanism in the Mediterranean Area. Geological Society of America Special Papers 418, pp. 17-31

Pe-Piper, G., Piper, D.J.W., \& Perissoratis, C. (2005). Neotectonics and the Kos Plateau Tuff eruption of $161 \mathrm{ka}$, South Aegean arc. Journal of Volcanology and Geothermal Research 139, 315-338. DOI: 10.1016/j.volgeores.2004.08.014

Perugini, D., Poli, G., Christofides, G., Eleftheriadis, G., Koroneos, A., \& Soldatos, T. (2004). Mantle-derived and crustal melts dichotomy in northern Greece. spatiotemporal and geodynamic implications. Geological Journal 39, 63-80 DOI: 10.1002/gj.944

Peterson, T.D., Esperanca, S., \& Le Cheminant, A.N. (1994). Geochemistry and origin of the Proterozoic ultrapotassic rocks of the Churchill Province, Canada. Mineralogy and Petrology 51, 251-276. DOI: 10.1007/BF01159732

Petrakakis, K., Zamolyi, A., Iglseder, C., Rambousek, C., Grasemann, B., Draganits, E., \& Photiades, A. (in press). Geological map of Greece. Serifos island sheet 1.50.000.I.G.M.E., Athens, Greece

Pipera, K. (2015). Study of the high potassium magmatism in Northern Greece. Implications for the mantle Geochemistry and the Geodynamic evolution of the area. PhD Thesis. University of Thessaloniki, Thessaloniki, Greece, $324 \mathrm{p}$

Poli, G., Christofides, G., Koroneos, A., Soldatos, T.,Papadopoulou, L., Manetti, P., Papadopoulos, A., \& Rocchi, S. (2012). Petrogenesis of Eocene Agios Gregorios Plutonic Complex (Mt. Athos, Chalkidiki, Greece): interplay between magma mixing, assimilation, and fractional crystallization. Acta Vulcanologica 25(1/2), 121-152

Prelević, D. (2010). The role of magma mixing in the origin of minette lamprophyres. examples from Mediterranean Tertiary volcanic provinces. Mineralogia Special Papers 37, 52-54

Prelević, D., Foley, S.F., \& Cvetkovic, V. (2007). A review of petrogenesis of Mediterranean Tertiary lamproites. A perspective from the Serbian ultrapotassic province. In. Beccaluva, L., Bianchini, G., \& Wilson, M. (eds). Cenozoic Volcanism in the Mediterranean Area. Geological Society of America Special Papers 418, pp.113-129

Puchelt, H., Murad, E., \& Hubberten, H.W. (1977). Geochemical and petrological studies of lavas, pyroclastics and associated xenoliths from the Christiana Islands, Aegean Sea. Neues Jahrbuch fur Mineralogie Abhandlungen 131, 140-155

Rock, N.M.S. (1991). Lamprophyres. Blackie and Son Ltd., Glasgow, U.K., 285 p

Roussos, N. (1993). Geological map of Greece. Limnos island sheet (Myrina and Moudros) 1.50.000. I.G.M.E., Athens, Greece 
Satian, MA., Sahakyan, LH., \& Stepanyan ZH. (2009). Composition of tuffs from lamprophyre diatremes of the Vedi rift, Armenia. Lithology and Mineral Resources 44(4), 399 DOI: 10.1134/S0024490209040087

Scarrow, J., Molina, J.F., Bea, F., Vaughan, A. (2011). Lamprophyre dikes as tectonic markers of late orogenic transtension timing and kinematics. A case study from the Central Iberian Zone. Tectonics 30(4), 1-22. DOI: 10.1029/2010TC002755

Searle, M.P. (1984). Alkaline peridotite, pyroxenite and gabbroic intrusions in the Oman Mountains, Arabia. Canadian Journal of Earth Sciences 21, 396-406 DOI: 10.1139/e84-043

Sergi, A. (1997). Mafic microgranular enclaves from the Xanthi pluton (Northern Greece). an example of mafic-felsic magma interaction. Mineralogy and Petrology 61, 97-117 DOI: 10.1007/BF01172479

Skarpelis, N.S., Kyriakopoulos, K., \& Villa, I. (1992). Occurrence and ${ }^{40} \mathrm{Ar} /{ }^{39} \mathrm{Ar}$ dating of a granite in Thera (Santorini, Greece). Geologische Rundschau 81, 729-735 DOI: 10.1007/BF01791388

Soder, C. (2017). Geochemistry and petrology of lamprophyres from the Hellenides and the European Variscides. PhD Thesis. University of Heidelberg, Heidelberg, Germany, $201 \mathrm{p}$

Soder, C., Altherr, R., \& Romer, R.L. (2015). Mantle metasomatism in a complex subductioncollision scenario: The Late Miocene lamprophyres from the Island of Kos (SE-Aegean). Goldschmidt Abstracts, Prague, Czech Republic, 2938

Soder, C., Altherr, R., Romer, R. (2016). Mantle metasomatism at the edge of a retreating subduction zone. Late Neogene lamprophyres from the island of Kos, Greece. Journal of Petrology 57(9), 1705-1728. DOI: 10.1093/petrology//egw054

Soldatos, T., Poli, G., Christofides, G., Eleftheriadis, G., Koroneos, A., \& Tommasini, S. (1998). Petrology and evolution of transitional alkaline- subalkaline granitoids from Vrondou (NE Greece). evidence for fractional crystallization and magma mixing. -Acta Vulcanologica 10(2), 319-330

Spišiak, J. (2010). Lamprophyres of the Western Carpathian crystalline complexes; petrology and geochemistry. Mineralogia Special Papers 37, 59-60

Stouraiti, C. (1995). Geochemistry and petrogenesis of the Serifos granite, in relation to other Aegean granitoids, Greece. PhD Thesis, University of Leicester, Leicester, U.K., 249 p

Stouraiti, C., Baziotis, I., Asimow, P.D. \& Downes, H. (2018). Geochemistry of the Serifos calcalkaline granodiorite pluton, Greece. constraining the crust and mantle contributions to I-type granitoids. International Journal of Earth Sciences 107(5), 1657-1688 DOI: 10.1007/s00531-017$1565-7$

Streckeisen, A. (1978). IUGS Subcommission on the Systematics of Igneous Rocks. Classification and nomenclature of volcanic rocks, lamprophyres, carbonatites and melilitic rocks. Recommendations and suggestions. Neues Jahrbuch fur Mineralogie Abhandlungen 134, 1-14

Sutphin, D., Hammarstrom, J., Drew, L., Large, D., Berger, B., Dicken, C. \& DeMarr, M. (2013). Fakos. U.S. Geological Survey, Mineral Resources Data System. Retrieved April 7, 2019 from U.S. Geological Survey database: https.//mrdata.usgs.gov/mrds/. DOI: 10.3133/sir20105090K

Tappe, S., Foley, S.F., Jenner, G.A., \& Kjarsgaard, B.A. (2005). Integrating Ultramafic Lamprophyres into the IUGS Classification of Igneous Rocks. Rationale and Implications. Journal of Petrology 46(9), 1893-1900. DOI: 10.1093/petrology/egi039

Taylor, G.K. (1988). A palaeomagnetic study of a Caledonian ophiolite. Geophysical Journal International 94(1), 157-166 DOI:10.1111/j.1365-246X.1988.tb03435.x

Tomkeieff, S.I., Walton, E.K., Randal, B.A.O., Battey, M.H., \& Tomkeieff, O. (1983). Dictionary of Petrology. Wiley, New York, U.S.A., $680 \mathrm{p}$

Tröger, W.E. (1969). Spezielle Petrographie der Eruptivgesteine. Verlag der Deutschen Mineralogischen Gesellschaft, Stuttgart, Germany, $440 \mathrm{p}$ [in German].

Tsoukalas, N. (2008). Stratigraphy of the Upper Miocene Volcanic rocks of the Island of Kos, Greece. Geodynamic Implications. MSc Thesis, Saint Mary's University, Halifax, Canada 
Ulrych, J., Adamovic, J., Krmíček, L., Ackerman, L., \& Balogh, K. (2014). Revision of Scheumann’s classification of melilitic lamprophyres and related melilitic rocks in light of new analytical data. Journal of Geosciences 59(1), 3-22 DOI: 10.3190/jgeosci.158

Vasilatos, Ch. (2013). Comparative study of the trace element and rare earth geochemistry of the Tertiary granitic bodies of Central Macedonia which are related or not to a well-known metallogeny - Identification of the geotectonic environment of genesis of the source magma of the granitic bodies. PhD Thesis. University of Athens, Athens, Greece, 502 p. [in Greek]

Voudouris, P. (2006). A comparative mineralogical study of Te- rich magmatic- hydrothermal systems in northeastern Greece. Mineralogy and Petrology 87, 241-275. DOI: 10.1007/s00710006-0131-y

Voudouris, P. (2010). Gold deposits in Greece. mineralogy and genetic considerations. Invited Lecture. S.M.E.G.D. in association to GSA-NSW Division. DOI: 10.13140/RG.2.2.35852.00643

Voudouris, P., Melfos, V., Spry, P. \& Baker, T. (2016). Cenozoic Porhyry-Epithermal and Other Intrusion-Related Deposits in Northeastern Greece. Geological, Mineralogical and Geochemical Constraints. In. Voudouris, P., Siron, C., \& Marton, I. (eds). Eocene to Miocene Hydrothermal Deposits of Northern Greece and Bulgaria. Relationships Between Tectonic-Magmatic Activity, Alteration and Gold Mineralization. Guidebook Series of the Society of Economic Geologists 54, pp. $43-82$

Wilson, M. (1989). Igneous Petrogenesis. Hyman, London, U.K., 466 p

Wimmenauer, W. (1977). Lamprophyres and associated rocks in the dike suite of the Dikeos monzonite, Kos (Greece). Annales Géologiques des Pays Helléniques 28, 427-435

Woolley, A.R., Bergman, S.C., Edgar, A.D., Le Bas, M.J., Mitchell, R.H., Rock, N.M.S., \& Smith, B.H.S. (1996). Classification of lamprophyres, lamproites, kimberlites, and the kalsilitic, melilitic and leucitic rocks. Canadian Mineralogist 34,175-186

Xydous, S. (2018). Late-stage B-bearing fluid circulation in the Kavala pluton. Evidence from mineralogical, spectroscopic and geochemical data in tourmaline-rich fault-related rocks. MSc Thesis, University of Athens, Athens, Greece, $87 \mathrm{p}$

Zananiri, I. (2004). Contribution to the study of the geotectonic evolution of the Rhodope massif with the application of magnetic methods (AMS Anisotropy of Magnetic Susceptibility) in granitic rocks. PhD Thesis. University of Thessaloniki, Thessaloniki, Greece, 255 p. [in Greek]

Zouzias, D. (2011). Sustainable Development of the Nisyros volcano and new volcanological characteristic data of the broader area and with the help of remote sensing. PhD Thesis. University of Patras, Patra, Greece, $511 \mathrm{p}$ [in Greek]. 